\title{
ACRL strategic plan: Final draft
}

\section{$A$ new mission and vision for ACRL}

工 he decision to develop a new strategic plan, made by the Association of College and Research Libraries Board of Directors at the 1994 ALA Annual Conference, was based on a number of factors, but it was primarily initiated because of an awareness of the rapid rate of change that was impacting ACRL and member needs, and the fact that the existing plan did not provide the mechanism for the association to respond.

The Board of Directors felt that planning would:

- create a clear understanding of reasons why the Association of College and Research Libraries (ACRL) should continue to exist;

- enable ACRL to more effectively recognize its role as the future evolves;

- maximize ACRL's ability to shape, rather than be shaped by, the external environment;

- provide for maximum coordination of ACRL programs, benefits, and services with higher education and information-related organizations;

- provide for increased accountability for results.

The existing ACRL strategic plan was approved by the Board of Directors in 1986 and became effective with the 1987 association program year. The plan was monitored by the Planning Committee and recommendations were made to the Board of Directors. ACRL units identified programs that supported the plan, completed action inventory forms annually detailing results, and submitted the forms to the Planning Committee.
The units' summaries of results were used to form the basis of the ACRL Operating Plan and the Annual Report.

The 1986 ACRL Strategic Plan remained in effect through 1994 when the Board of Directors voted to suspend the plan and, at its meeting on June 28, 1994, established a Strategic Planning Committee. The Board decided that because of the rapid rate of change, the plan should cover a three- to five-year period.

The 1994 Strategic Planning Committee met in a two-day session, September 23-24, 1994, in two two-hour sessions during the 1995 ALA Midwinter Meeting, and a two-hour session at the close of the ACRL National Conference in Pittsburgh. A listserv, ACRLPlan, was established to facilitate the work of the committee. The meetings and listserv provided opportunities for the committee to review information and data and to develop the plan presented here.

\section{Strategic Planning Committee}

The members of the Strategic Planning Committee were from the Planning Committee and the Board of Directors. The members of the Planning Committee were representative of nearly every constituency within ACRL's membership: community and junior college libraries, college libraries, and university libraries. The members of the Board of Directors included the three officers: president, vice-president, and past-president, two members-atlarge, and the executive director.

A majority of the committee members attended all meetings of the committee and participated in discussions over the Internet. 1994 Strategic Planning Committee: Charles Forrest, Emory University; Patricia Breivik, Wayne State University; Charlotte Hess, Indiana University; Sandra Ready, Mankato State University; Kristine Brancolini, Indiana University; Douglas Lehman, Miami-Dade Community College; Keith Russell, National Agricultural Library; Carla Stoffle, University of Arizona; Frances Maloy, Emory University; Thomas Kirk, Earlham College; Robert Marks Ridinger, Northern Illinois University; Susan Martin, Georgetown University; Mary Reichel, Appalachian State University; Virginia O'Herron, Old Dominion University; David Walch, California Polytechnic State University; Althea H. Jenkins, ACRL Executive Director; Facilitator: Maureen Sullivan. 


\section{The planning process}

The Strategic Planning Committee began its work by reviewing and discussing foundation data: 1993 membership survey results, external and internal environmental scan, and information from Board/Leadership planning sessions that included strengths and weaknesses; values; assumptions; and critical issues. Also included was a discussion of the association's organizational structure.

In preparation for its discussions and development of a mission statement, the committee identified strategic areas. This exercise insured that no major areas vital to the future of the association were overlooked. The mission statement was the first element of the plan to be developed. Because of its extreme importance to the entire planning process, considerable time and effort was expended in both developing and reviewing the mission statement

As the planning process proceeded, each objective and strategy was checked against the mission statement to be sure it fell within its scope.

The Strategic Planning Committee clarified the vision that would provide the impetus for the entire planning process. The committee used the vision to address the opportunities it saw for ACRL.

The next step in the planning process was the development of goals. The committee reviewed foundation data: environmental scan, strengths and weaknesses, issues, opportunities, and survey results in order to begin the goals-development process. The committee identified four goals which were responsive to changes in academic librarianship and ACRL

The committee agreed to develop strategic directions, rather than objectives, for each goal

\section{Share your library's news}

CERL News wants to hear about your library's activities. Information in the News from the Field, Grants \& Acquisitions, and People in the News columns is gathered from press releases and notices we receive. If you don't share your ideas and activities with us we can't share them with CGRL News readers. Be sure to put CERL News on your mailing list today. Send notices to the Editor, CERL News, 50 E. Huron St., Chicago, IL 60611; or e-mail mary.ellen.davis@ala.org.
Strategic directions were reviewed by the committee as being results-oriented, measurable, relatively short-term, and easily linked to operational programs. Strategic directions were developed for each of the goals.

\section{Review/drafting process}

After the committee's September 23-24, 1995, meeting, a draft was made for the ACRL Executive Committee for review and comment. Their comments and suggestions were discussed by the committee and, where appropriate, incorporated into the plan. A second draft of the mission statement, vision statement, and goals was sent to all invitees to the ACRL Midwinter Board/Leadership Planning Session. Appropriate comments and suggestions were incorporated into a third draft of the plan and formed the basis of the committee's discussion in Pittsburgh

The draft was reviewed by the committee and put into the final draft form for the ACRL Executive Committee review at its spring meeting, April 21-22, 1995. ACRL members have an opportunity to comment on the plan during the ACRL Planning Session at the AlA Annual Conference, June 23, 3:00-5:00 p.m.

The Strategic Plan which follows this de scription of the planning process represents an immeasurable amount of time by each com mittee member in thought, meetings, and preparation for committee meetings.

\section{Mission}

The Association of College and Research Libraries (ACRL) provides leadership for development, promotion, and improvement of academic and research library resources and services to facilitate learning, research, and the scholarly communication process.

ACRL promotes the highest level of profes sional excellence for librarians and library personnel in order to best serve the users of academic and research libraries.

\section{Vision}

Together, ACRL members will strengthen the ability of academic and research librarians and other library personnel to provide superior services and resources for their communities; and will prepare academic and research librarians to play increasingly significant roles in higher education. ACRL will provide leadership in shaping education, information, and scholarly communication policy. It will achieve this 
through partnerships with higher education and information technology organizations, national forums, and through the legislative process. ACRL will recruit and help to retain highly qualified and talented librarians who reflect the diversity found in American society. ACRL will develop standards for professional preparation and promote continuous learning for academic and research librarians and other library personnel.

\section{Goals}

1. Provide development opportunities for academic and research librarians and other library personnel.

Strategic directions

1.1 ACRL will support activities which strengthen formal and informal networking opportunities for academic and research librarians and library personnel to discuss and share ideas, knowledge, experiences, and expertise.

1.2 ACRL will support recruitment efforts to bring into the profession those individuals who will enrich the diversity of the profession.

1.3 ACRL will develop and implement an ongoing mechanism for providing national programming regionally to support continuing education needs.

1.4 ACRL will continue to seek ways to increase membership participation in its activities.

\section{Maintain at the national level a promi- nent role in planning and decision- making for influencing information policy.}

Strategic directions

2.1 ACRL will provide financial support for the ALA Goal 2000 technology initiative and legislative agenda to insure that the items of concern to academic librarians receive prompt attention.

2.2 ACRL will support the ALA Washington Office in responding to issues affecting academic libraries and higher education.

2.3 ACRL will use an effective communication mix to promote an understanding of the value and contributions of academic/research librarians and libraries to higher education and society in general.

2.4 ACRL will participate in activities of higher education and other organizations to inform these groups of the value of library resources and services and the library's role in the teaching/learning and scholarly process.

\section{Planning roles for ACRL}

\section{Board of Directors}

- Sets overall direction and communicates that direction to the association;

- assures alignment of overall and unit planning;

- identifies continuing and current priorities;

- establishes procedures to facilitate units' response to the strategic plan;

- evaluates and updates strategic plan;

- revises mission, vision, goals, strate gic directions, and priorities.

\section{President and Vice-President/President- \\ Elect}

- Defines activities in support of ACRL strategic directions;

- with Executive Director, guides Board interpretation of plan in relation to programs.

\section{Executive Director}

- Develops environmental scan;

- interprets plan to membership and general public;

- completes annual report of ACRL and units accomplishments in relation to strategic directions;

- assists President and Board with development of implementation plan;

- sets schedule and sequence for evaluation and review of plan.

\section{Units}

- Within the ACRL Strategic Plan, identify unit priorities that support goals and strategic directions;

- develop activities that support unit priorities;

- complete annual report of unit accomplishments in relation to strategic directions;

- contribute to overall ACRL strategic planning process.

(Plan cont. on page 412) 


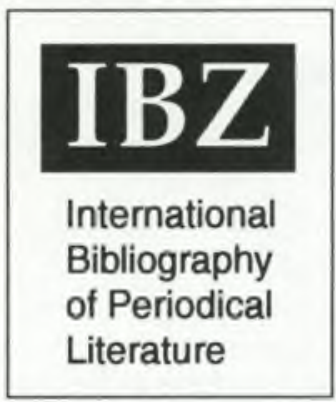

\section{Humanities as Priority „one“ The \\ powerful connection}

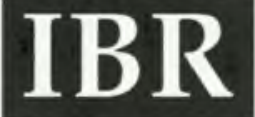

International Bibliography of Book reviews

\section{9-1993}

Over 650000 titles of articles published between 1989-1993

140000 new records added annually in two updates

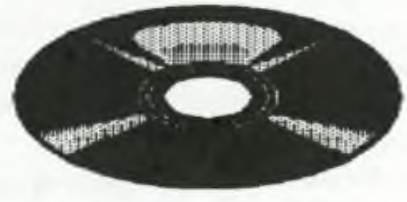

now on CD-ROM

\section{5-1994}

Citations to over 400000 book reviews in scholarly and scientific journals

50000 new records added annually in two updates

\section{New: \\ Leistner / Becker \\ $6^{\text {th }}$, considerably enlarged edition will appear in June 1995 Subscription price: until July 31, 1995 DM 790,-

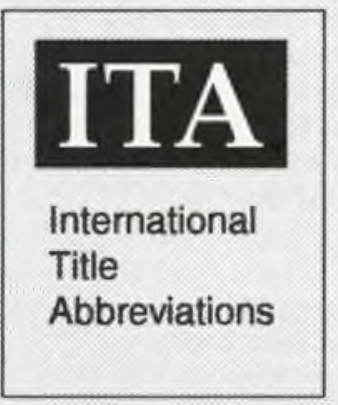 \\ „... an indispensable, frequently consulted standard work..." \\ (Zeitschrift für Bibliographie und Bibliothekswesen (thereafter DM 890,-) 37 [1990] 6)}

\section{A L A}

\section{Annual Conference}

June 24-27, 1995

Chicago, IL

Convention Center

Location 640
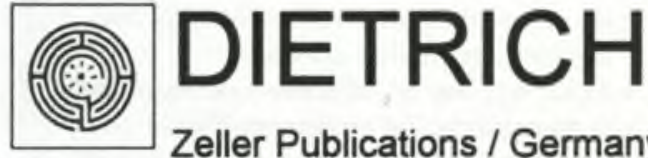

Zeller Publications / Germany Jahnstraße 15, 49080 Osnabrück Telefon 0541/4 04 59-0 Fax 0541/4 1255 
pertise. If you do not believe you have something to offer, how can you expect others to believe you do?

Librarians who have academic administrators who are unsympathetic to or uninformed about libraries have a special challenge. They should ask the administrators how they acquired their views of the library, identify these administrators' interests, and be supportive of their projects. Perhaps the administrators would find appropriate information summaries helpful. Librarians may want to involve these administrators in libraries; invite them to selected meetings and create situations that spark their interests and require their participation. In such an environment, the education and cultivation of several groups may be essential. Some librarians use information forums for people with vested interests in the library as a way of educating them and establishing a commonality. Besides accreditation standards, the assessment movement provides librarians with enhanced opportunities to be involved with and document their contributions to students' education.

There has always been a shortage of creative leaders and managers within higher edu- cation. The need for them is growing more acute. Campus leadership roles will be filled with or without librarians. Librarians must make the investment and position themselves and their expertise. Do not wait to be asked. $\mathrm{Li}^{-}$ brarians must lead by example and develop the leadership skills of other librarians. Identify potential leaders and hegin with a small project. Be supportive as they build confidence. Partner these individuals with others who are more experienced. Mentor them and collaborate with them on professional activities. Work with support staffs to help them understand the changing dynamics.

A point in favor of potential campus leaders is that organizations draw most of their leaders from within their ranks. Colleges are more comfortable with people they know and respect. Outsiders are unknown quantities and can be more of a risk than some colleges are prepared to take.

Librarians are encouraged to take the initiative and develop as campus leaders. While there are risks, it is not only a good personal experience, but is also good for the library and the campus.
(Plan cont. from page 403)

\section{Collaborate with other professional or- ganizations and associations of higher education in order to promote mutual interests.}

\section{Strategic directions:}

3.1 ACRL will participate in activities of, and seek cooperative relationships with, higher education associations such as AACU, AACC, AAHE, ACE, AASCU, AAU, NAICU, and NASULGC.

3.2 ACRL will seek cooperative relationships with CNI, CAUSE, EDUCOM, AECT, ASIS, and other information-related associations to develop cooperative initiatives to enhance and expand the library's role as central to academic endeavors.

\section{ARL.}

3.3 ACRL will strengthen its relationship with

3.4 ACRL will work with higher education and scholarly associations to protect access to intellectual property in electronic environments.

4. Ensure that ACRL's operating environment provides efficiency in its use of resources and effectiveness in the delivery of services to its members and constituent units.

\section{Strategic directions:}

4.1 The ACRL Board of Directors will take responsibility for planning in order to provide organizational direction.

4.2 ACRL will develop and maintain an integrated dynamic management system and process that include: a strategic plan, a financial plan, and product-line marketing or business plans.

4.3 Members of the ACRL Board of Directors will act with the mission, vision, and goals of the association in mind, and see that issues and ideas are examined and discussed openly and thoroughly with the membership.

4.4 ACRL will examine and modify as appropriate its current structural arrangements to enhance its influence on information policy setting and legislation through better coordination of national and state efforts.

4.5 ACRL will review and revise its bylaws to reflect the roles of the Board of Directors and all ACRL units.

4.6 ACRL will keep informed of current association management practices and appropriate technologies to ensure that it operates at an optimum level of efficiency. 